\title{
Square Meter
}

National Cancer Institute

\section{Source}

National Cancer Institute. Square Meter. NCI Thesaurus. Code C42569.

A SI unit of area measurement equal to a square whose sides are one meter long.

Square meter is equal to 10,000 square centimeters; 0.01 are; 1.196 square yards; 10.76 square feet; 1550 square inches. 